\title{
PUBLIC OPINION REGARDING ALTERNATIVE MEDICINE
}

\author{
MERRYL HAMMOND \\ B.Soc.Sc.(Nursing), B.Soc.Sc.(Hons)
}

\section{OPSOMMING}

'n Steekproef van 47 Blanke Suid-Afrikaners is bestudeer met die oog op hulle ervaringe van en houding teenoor nieortodokse genesers. Die uitslag van die beperkte ondersoek beklemtoon die uiters mitiese aard van wat deurgaan vir wat algemeen bekend is oor alternatiewe praktisyns. Verskeie bedenksels word ondersoek en daar word tot die slotsom gekom dat Blanke Suid-Afrikaners gewoonlik deeglik bewus is van die keuses wat gesondheidsorg hulle bied; dat oor die $50 \%$ mense in alle statusgroepe ten minste van een alternatief in die verlede gebruik gemaak het; dat sodanige optrede nie gewoonlik as afwykend beskou word nie; dat dit as hoogs effektief in $69 \%$ en goedkoper as mediese sorg in $60 \%$ gevalle gevind is. Met die oog op hierdie feite word sekere aanbevelings gedoen.

\section{INTRODUCTION}

Fairly widespread disillusionment in medicine since the 1950s (when many wonder drugs proved themselves either ineffective or harmful - or both, and when disease was found to be as prevalent as ever, even if in degenerative and stressrelated guises), ${ }^{1)}$ seems to have coincided with considerable public interest in alternative forms of healing. Some authors have given sympathetic attention to alternatives like homeopathy, chiropractic, herbalism and so on, ${ }^{2)}$ but most of the literature still deals with these healers in a patronising if not blatantly biased manner. ${ }^{3), 4)}$ The abundance of emotive, highly critical reporting in the popular press, ${ }^{5)}$ coupled with the relative lack of detailed, up-to-date studies and the persistence of ideas put forward by those in positions of power and status has caused a situation where most common knowledge about alternatives is nothing short of mythical.

The prevalence of these myths was made clear following recent local research into alternative healers. Several patients had mentioned their use of alternatives and expressed a lack of confidence in medicine, and aroused the author's interest initially. She was also conscious of fairly general professional tolerance of black patients and their detours to witchdoctors and divi- ners, while no such tolerance existed at the mention of white patients and their recourse to various alternative healers. The author therefore set out to study the phenomenon of use of alternative healers among White South Africans in order to learn when and why they consulted these healers and how they evaluated their treatments. The author believes it is essential for health workers to know as much about the total illness behaviour of their patients as possible, and trusts that the insights gained from the present study will make a small contribution in this direction.

\section{THE SAMPLE AND METHOD}

The population under study consisted of 47 White Durbanites who formed three distinct subsamples:

20 patients currently attending the outpatient department of the large provincial hospital

18 randomly selected residents from one of Durban's elite suburbs, and

9 chiropractor's patients

In selecting a subsample from hospital outpatients, the sister-in-charge of two clinics assisted the author by handing out forms to the first sixty outpatients who attended on certain days. They were asked to help a researcher from the university who was studying health and illness in Durban, by filling in their names and addresses if they would not mind being interviewed. The people thus had no idea that the researcher was also a nurse, or that her major interest was in alternative medicine. The author is therefore confident that the 27 completed forms received were from people who were unlikely to be biased against modern medicine or in favour of alternative medicine, firstly because they had no idea what aspects of health and illness were under study, and secondly because they had to return the forms to the nursing sister - a member of the orthodox medical team. Of the 27 replies received, only twenty could finally be interviewed due to language and distance problems.

The eighteen suburbanites were selected randomly (every third house in predetermined streets), and of the 23 designated homes, refusals were received from three occupants and two others procrastinated for so long, that they were eventually counted as refusals. Once again, the researcher is confident that this sample was representative of the people in the whole upper class residential area from which it was drawn, and that the results can be generalised to other groups with similar educational, occupational and financial backgrounds.

This confidence does not, however, extend to the chiropractic 
subsample, and this group can in no way be considered typical or representative. The chiropractor himself handed out forms (as were used in the hospital) wherever I remembered to - so that the researcher has no idea how many, refusals there were before fifteen completed forms were received. Of these, only nine could eventually be interviewed due to transport and language problems as well as subsequent refusals.

The central technique used was the interview. Interviews were conducted in the respondent's own homes and the schedules were divided into seven sections, only three of which are discussed here. The first of these dealt with awareness and past use of various healing practitioners including five orthodox ones:

- surgeons

- doctors

- dermatologists

- psychiatrists

- chemists

and seven alternative healers:

- chiropractors

- homeopaths

- herbalists

- naturopaths

- Christian scientists

— faith healers

- acupuncturists.

The next section dealt specifically with alternatives if the respondent had ever consulted one (for example: Did you find that the alternative treatment helped you? and How did you contact that particular practitioner? The interview was concluded with several personal and socio-economic questions.

Supplementary techniques, not discussed here, included a period of participant observation at a chiro- practor's rooms before interviewing commenced (in order to sensitise the researcher to an entirely foreign world), and a postal survey carried out in upper and lower-class areas of Durban after the interviewing had been completed.

\section{RESULTS}

\section{Awareness of alternatives}

None of the overseas literature revealed any great awareness of alternatives among members of the public - on the contrary, such awareness seemed to be the exception. $\left.{ }^{6}\right)$ The results in Durban, however, show that Whites are fairly well aware of the options in health care being offered. Only $11 \%$ of the sample were relatively uninformed; $64 \%$ could describe the techniques and/or philosophies of four or five of the seven listed alternative healers; and $26 \%$ were familiar with six or all seven of them.

It was interesting to note that when respondents were classified on educational and occupational status indices ${ }^{7)}$ and were divided into status categories I, II and III in descending order of status, it was category II respondents who were by far the most aware and knowledgeable about alternatives. In this group, $38 \%$ knew six or seven of the healers, while only $23 \%$ of group I and $13 \%$ of group III did. I would postulate that category II people generally lack the personal and family ties with the medical profession that many category I people have, and are less conservative than many category III people are. This combination of factors seems to make the category II respondents more broad-minded and interested in alternatives than other people.

\section{Use of alternatives}

The limited research that has been done has always concluded that alternative use is not very widespread and that when it does occur, it is lower class people who tend to detour. ${ }^{8), 9)}$ The implication is that these people, being poorer, less educated, and relatively isolated from the mainstream, do not learn to value the benefits of scientific treatment and are not subject to censure from friends and family if they do indulge in deviant practices.

The results of the present study reveal a different picture entirely, as table 1 shows.

Alternative use is, in fact, a very widespread phenomenon. A total of 29 respondents $(62 \%)$ had used at least one alternative healer in the past. When the biasing effect of the chiropractic subsample is excluded, the figure remains at $53 \%$.

When the distribution of use of alternatives according to status category, is considered there is evidence of a changing trend. In the hospital subsample (mean age: 65 years), it is obviously a status category III phenomenon as table 1 shows. This seems to confirm the overseas data derived from studies done about thirty years ago. In the entirely upper class suburban subsample (mean age: 42 years) on the other hand, $39 \%$ had already consulted at least one alternative (despite their relative youth and good health). $78 \%$ of them (that is all except four women who were doctors' or chemists' wives) said that they would be likely to consult an alternative in future. Thus, the older upper class people in the hospital group were very prejudiced against non-professional healers, while the younger ones in the suburban group are much less so. The

\section{TABLE 1 PAST USE OF ALTERNATIVES BY SUBSAMPLE AND STATUS CATEGORY}

\begin{tabular}{|c|c|c|c|c|c|c|c|c|c|c|c|c|}
\hline \multirow[b]{3}{*}{$\begin{array}{l}\text { Socio-economic } \\
\text { status category }\end{array}$} & \multicolumn{12}{|c|}{ SUBSAMPLE } \\
\hline & \multicolumn{4}{|c|}{ Hospital } & \multicolumn{3}{|c|}{ Suburban } & \multicolumn{4}{|c|}{ Chiropractic } & \multirow[t]{2}{*}{ TOTAL } \\
\hline & I & II & III & Total & I & II & Total & I & II & III & Total & \\
\hline $\begin{array}{l}\text { PAST USE } \\
\text { Never } \\
\text { Ever }\end{array}$ & $\begin{array}{l}6 \\
3 \\
\end{array}$ & $\begin{array}{l}1 \\
3 \\
\end{array}$ & $\begin{array}{l}0 \\
7\end{array}$ & $\begin{array}{r}7 \\
13 \\
\end{array}$ & $\begin{array}{r}10 \\
6 \\
\end{array}$ & $\begin{array}{l}1 \\
1 \\
\end{array}$ & $\begin{array}{r}11 \\
7 \\
\end{array}$ & $\begin{array}{l}0 \\
1\end{array}$ & $\begin{array}{l}0 \\
7 \\
\end{array}$ & $\begin{array}{l}0 \\
1 \\
\end{array}$ & $\begin{array}{l}0 \\
9 \\
\end{array}$ & $\begin{array}{l}18 \\
29 \\
\end{array}$ \\
\hline TOTAL & 9 & 4 & 7 & 20 & 16 & 2 & 18 & 1 & 7 & 1 & 9 & 47 \\
\hline
\end{tabular}


comments of this latter group reflect their tolerant, broad-minded attitudes: I have no prejudice against them and I would go to anyone who could help me. (The doctors' wives were more wary, but one stated quite openly: I think we doctors' wives would use more alternatives but our husbands would be mad. If I went to one I'd have to keep very quiet about it ...). The writer predicts that in years to come research will reveal an even greater use of alternatives in all social groups - disillusionment with medicine, tolerance of many deviant practices and a striving for good health at any cost will account for this.

\section{Manner of introduction to al- ternatives}

It is common knowledge that use of alternatives constitutes deviant illness behaviour and that people generally try to conceal their deviance from others. Interview respondents who had consulted an alternative were asked: How did you contact that particular practitioner? In $84 \%$ of cases the person said that a relative or friend had personally recommended the alternative. This seems to indicate that people talk freely of their experiences and others openly ask advice. In other words, use of alternatives is not considered to be a shameful deviance to be concealed from others. All-in-all, $97 \%$ had friends or relatives in some way involved in their decision to consult a healer:

$62 \%$ had them both recommending and currently consulting the same healer,

$22 \%$ had them just recommending, and

$13 \%$ had friends or relatives just consulting the healer concerned.

This willingness to speak about alternatives, however, did not extend as far as doctor-patient interactions. The amount of co-operation between orthodox and non-orthodox practitioners is minimal, and people are painfully aware of this. Some typical comments: $M y$ doctor would kill me if he knew I was going there, (to the chiropractor); He'd be so upset to know that I've gone behind his back. . . Yet, as the results so plainly show, many prefer to consult an alternative anyway and to live with their feelings of guilt.

\section{The last resort theory}

In seeking to explain the apparently irrational use of alternatives by educated people, some authors have theorised that they only go in desperation, as a iast resort, in the event of a terminal illness. ${ }^{10)}$ Indeed, one herbalist claimed to be a specialist in curing the incurables because so many of his patients had been pronounced incurable by the orthodoxy. ${ }^{11)}$

The interview data indicates that the majority of disorders $(62 \%)$ that were eventually treated by an alternative had first been medically treated. Many people had taken courses of drugs, had been given physiotherapy and even major surgery before going to an alternative in sheer desperation. So the last resort theory does apply in most cases. Nevertheless, $38 \%$ of cases were taken directly to an alternative practitioner. In other words, many people are bypassing medical treatment entirely - presumably because they anticipate that it will be ineffective.

This last remark is substantiated by the finding that particular disorders are taken to particular practitioners for treatment. For example, it was found that a high incidence of joint pains and arthritis were treated by acupuncturists; homeopaths seemed to be treating a high proportion of hormonal complaints; and chiropractors overwhelmingly treated backache and fibrositis. It would thus appear that certain healers have earned repu- tations for effective treatment of certain disorders and people decide who to consult, depending on their specific complaints. In other words, illness behaviour can be reviewed as a rational process in which people made conscious and deliberate decisions about whom to consult regardless of the healer's status as a professional or otherwise.

\section{Evaluation of alternative treatment}

One of the standard thoughts in orthodox circles is that alternative treatment is at best ineffective and at worst harmful. In the few cases that have apparently been successfully treated by a non-orthodox healer, the rallying and defensive cry is invariably: psychosomatic!

Interview respondents were asked to judge the effectiveness of the treatment they received: Did you find that your visits to, or treatment given by " $X$ " helped you? and then Do you still get (the symptom that was treated) these days? The results are shown in table 2.

Fully $91 \%$ said that they had been helped by the alternative treatment and $76 \%$ (or $69 \%$ of the total) of them had complete and permanent relief from the symptom which was treated. This really is a remarkable record for any practitioner, especially in the light of the fact that the majority of these people only consulted an alternative after orthodox medical treatment had failed...

\section{The money-grabber theory}

Perhaps the most common myth about alternative healers concerns their interest in making a fast buck. The following is quoted from an article in a popular magazine: ...

\section{TABLE 2 JUDGEMENT OF EFFECTIVENESS OF ALTERNA- TIVE TREATMENT AND CESSATION OF SYMPTOMS}

( $n=45$; there were 45 instances of treatment reported)

\begin{tabular}{|l|ccc|}
\hline \multirow{2}{*}{ SYMPTOMS } & \multicolumn{4}{|c|}{ JUDGEMENT } & OF EFFECTIVENESS \\
& YES & NO & TOTAL \\
\hline CEASED & 31 & 0 & 31 \\
CONTINUED & 10 & 4 & 14 \\
\hline TOTAL & 41 & 4 & 45 \\
\hline
\end{tabular}


quacks who prey on the troubled and the gullible, taking their money in return for ineffective and even harmful treatment. ${ }^{\text {s) }}$

It has been illustrated that people who have had the benefit of personal experience with such quacks do not find the treatment either harmful or ineffective. But how accurate is the image of the alternative healer as the money-grabber? How do their patients feel about the cost of the therapy? (The reader should note that the interviews were conducted some months before the most recent increases in medical fees and that the question was phrased: How did you feel about the cost of this alternative treatment compared with other medical treatment you have had?).

The vast majority of respondents found the cost of non-orthodox care to be either cheaper than $(60 \%)$ or at least comparable with (33\%) normal medical treatment. Only three people found it more expensive, and in two of these cases the therapy was acupuncture performed by a fully qualified medical practitioner. So yet another myth about alternatives is exposed...

\section{DISCUSSION}

On the basis of the tentative results of this study, the author would very much like to make certain recommendations, albeit controversial. Firstly, she would like to see increased publicity and objective reporting on alternative therapies in the media. Although people were generally well informed, it is believed that it would only be to their advantage to know more about the philosophies and techniques of the various healers, to assist them in making decisions relating to illness behaviour in future. The debate, discussion and exchange of ideas from all parties would be far healthier than the present situation.

Secondly, it is suggested that medical and nursing educators, administrators and practitioners be made aware of the fact that they are not the only healers in modern society and that over half of their White patients in fact consult alternatives as well. With a detailed knowledge of what alternative training entails, an understanding of the principles involved and an appreciation of the success of alternative therapy in many fields, orthodox practitioners might cease their automatic criticism of non-orthodox healers. Perhaps the tolerance that knowledge breeds will ultimately lead to acceptance of alternatives as alternatives, and even to active referral of intractable cases to appropriate healers.

Thirdly it is advocated that all medical aid schemes make provision for alternative treatment to be compensated. Given the effectiveness, the speed, and low cost of such treatment, it is inconceivable that people should be penalised for saving time, money and man-hours in seeking such care. Some schemes in South Africa now include chiropractic costs, so a start has been made in the right direction.

Fourthly, the question of training schools, especially for chiropractic and homeopathy, should be thoroughly investigated. The public seems to need and want these practitioners - must they continue to go abroad for training?

Finally, it is urged that regardless of the public's admiration, the desire for professional status, and even the orthodoxy's ultimate acceptance, alternative practitioners should do all in their power to retain their separate identities. Their value lies in their very differ- ence from orthodox methods and practitioners, and it would be a very sad day indeed if they were ever coopted into orthodox institutions as has happened in America with osteopathy.

\section{CONCLUSION}

Several of the common myths about alternative healers have been examined and explored through the eyes of some White Durbanites. It is believed that the findings from this study have great relevance for all health workers and they are urged to make a habit of studying alternative practices and therapies rather more objectively than is traditionally done in orthodox circles. There can be no doubt that modern medicine as we know it does not have all the answers to man's health problems - be they physical, emotional, social or psychosomatic. If the wellbeing of our patients is sincerely our major concern, are we not obliged to see that they find relief in someone's care -- even if that person's beliefs and practices stand in direct opposition to our own?

\footnotetext{
REFERENCES

1. Inglis, B: Fringe medicine. Faber and Faber. London. 1964. pp 18-54.

2. Blythe, P: Drugless medicine. Arthur Baker. London. - 1974

3. Glaser, G; Strauss. M: Awareness of Dying. Aldine. Chicago. 1965. p 131.

4. Coe, R M: The Sociology of medicine. McGraw-Hill. New Jersey. 1970. p 228

5. See, for example: Crackdown on Quackery. Life magazine. November 1, 1963. No 55. pp 72-83.

6. Wardwell, W: A Marginal Professional Role in Jaco, E G (Ed.) Patients, Physicians and Illness. The Free Press. U.S.A. 1958. 1st Edition. p 425.

7. Close, M: Die Meting van Maatskaplike Status en Statuskongruasie - unpublished M.A. Thesis, University of Natal, Durban. 1968. pp 56-57, 61-70.

8. Koos, E Metropolis: What Ciry People Think of their Medical Services. in Jaco, E G (Ed.) Op cit. The Free Press. U.S.A. Ist Edition. 1958. p 17.

9. Wardwell, W: Op cit. p 429.

10. Cobb, B: Why Do People Detour to Quacks? in Jaco E G (Ed.) $O p$ cit. pp 284-285.

11. Blythe, P (1974): Op cit. p 43
} 